Volume 9, Issue 1 (Winter 2017)

\title{
Collecting Old Masters for New York: Henry Gurdon Marquand and the Metropolitan Museum of Art
}

Esmée Quodbach

e.quodbach@gmail.com

Recommended Citation:

Esmée Quodbach, "Collecting Old Masters for New York: Henry Gurdon Marquand and the Metropolitan Museum of Art," JHNA 9:1 (Winter 2017), DOI: 10.5092/jhna.2017.9.1.2 Available at https://jhna.org/articles/collecting-old-masters-new-york-henry-gurdon-marquand-metropolitan-museum-of-art/

Published by Historians of Netherlandish Art: https://hnanews.org/

Republication Guidelines: https://jhna.org/republication-guidelines/

Notes: This PDF is provided for reference purposes only and may not contain all the functionality or features of the original, online publication. This PDF provides paragraph numbers as well as page numbers for citation purposes.

ISSN: 1949-9833 


\section{COLLECTING OLD MASTERS FOR NEW YORK: HENRY GURDON MARQUAND AND THE METROPOLITAN MUSEUM OF ART}

\section{Esmée Quodbach}

The subject of this article is the collector Henry Gurdon Marquand (1819-1902), banker and railroad financier, and a noted member of the burgeoning class of newly prosperous business magnates of Gilded Age New York. An exceptionally civic-minded patron, Marquand set out in the early 1880 s to assemble a group of first-class Old Master paintings for the Metropolitan Museum of Art. This paper explores Marquand's acquisitions, especially the Flemish and Dutch paintings he bought. Focusing on Marquand's 1889 gift of thirty-seven Old Masters to the museum - the first gift of its kind - this paper also considers Marquand's aspirations, not only as a major private collector but especially as a leading donor to the institution, whose second president he became in 1889. D0I:10.5092/jhna.2017.9.1.2

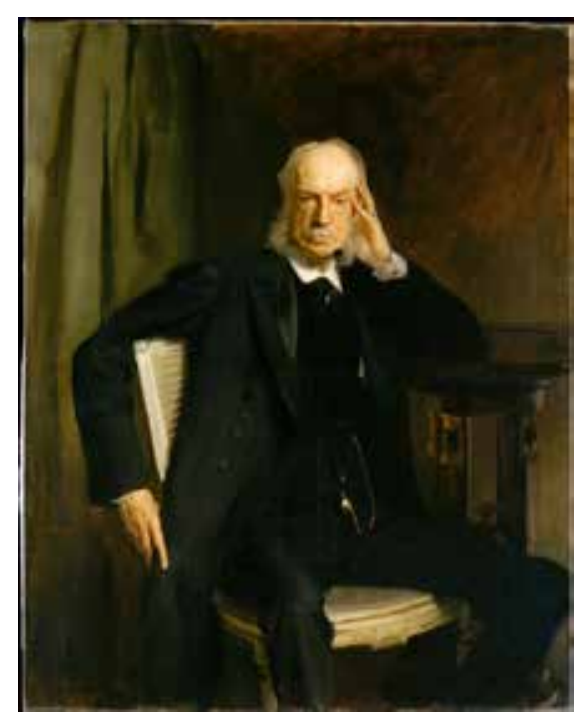

Fig. 1 John Singer Sargent (1856-1925), Henry Gurdon Marquand (1819-1902), 1897, oil on canvas, 132.1 x $106 \mathrm{~cm}$. New York, The Metropolitan Museum of Art, Gift of the Trustees, 1897, inv. 97.43 (artwork in the public domain; photo courtesy of the Metropolitan Museum of Art)

Henry Gurdon Marquand (fig. 1) was one of the great art collectors and philanthropists of late nineteenth-century New York. ${ }^{1}$ Ambitious, civic-minded, and unusually generous, he gave his support to the Metropolitan Museum of Art from its earliest days onward, making his mark both through his many gifts and his remarkable vision for the institution. A prominent tastemaker, Marquand was, according to his contemporaries, also responsible for the Old Master craze that swept New York in the final years of the nineteenth century. His tastes and aspirations have shaped the history of the Metropolitan Museum and, more indirectly, the history of many other 
museums in America.

2 A banker, broker, and railroad financier, Marquand was an eminent member of the emerging class of newly prosperous business magnates of Gilded Age New York. Born in the city in 1819, he left school when he was sixteen years old and started working in his family's silversmithing firm, Marquand \& Company. After his father's death, in 1838, the firm was sold and Marquand went into various other branches of business, including real estate investment and banking. In 1868, he also became involved with the St. Louis and Iron Mountain Railroad, serving as its vice-president from 1875 to 1881, and then as its president for a year. The sale, in December 1880, of twenty thousand shares of stock in the Railroad left Marquand with \$1 million, then an enormous fortune.

3 Marquand was well traveled-he first visited Europe in 1843, when he was in his mid-twenties, and reportedly it was during this trip that he became interested in the arts. He began collecting art in the 1840 s or 1850 s, initially concentrating on contemporary paintings and decorative objects. Over the years, he built friendships with many artists, among them a large number of expatriate Americans, who also advised him on his art purchases. Marquand's collecting and his interests in the arts were characterized by a strong sense of public purpose: he was, in 1869, a member of the so-called Provisional Committee to establish a museum of art in New York, becoming a trustee of the newly founded Metropolitan Museum in 1871 and its treasurer in 1882.

4 The museum's founders, Marquand among them, aimed to assemble an encyclopaedic collection, comprising paintings and sculpture as well as decorative arts, and even industrial arts. Marquand not only made large financial donations to the institution-including, for example, in 1886, $\$ 10,000$ for the acquisition of sculpture casts and, the following year, $\$ 30,000$ for the endowment of a museum art school-but he also presented gifts to virtually every curatorial department. His first nonmonetary gift to the museum dates to 1879, when he donated a collection of pre-Columbian Native American ceramics, known as Mound-Builders pottery. Several other gifts followed, among these, in 1881, the donation of the Jules Charvet collection of so-called ancient glass. Marquand's first gift of a painting took place that same year, when he donated John Trumbull's Alexander Hamilton. ${ }^{2}$

In the meantime, Marquand had also built a private picture collection, which, by the later 1880s, comprised a large and eclectic group of works, mostly British portraits, French landscapes, and contemporary British and American paintings. He kept his collection at his grand four-story mansion at 11 East Sixty-Eighth Street, on the corner of Madison Avenue, not far from "Millionaires' Row" (fig. 2). ${ }^{3}$ The exterior of Marquand's house, designed in the French Renaissance style by his friend Richard Morris Hunt, then New York's most sought-after architect, was completed in 1884. Its interior, influenced by the Aesthetic Movement and executed in a variety of styles, took several years longer to finish. Unlike some other leading collectors' residences in the city-for example, those of Alexander T. Stewart and William H. Vanderbilt-the mansion did not have a separate art gallery; Marquand's many paintings, his sculptures, and other art objects formed an integral part of its interior decoration. The centerpiece of Marquand's private collection was $A$ Reading from Homer of 1885, a large history painting commissioned from Sir Lawrence Alma-Tadema. ${ }^{4}$ 


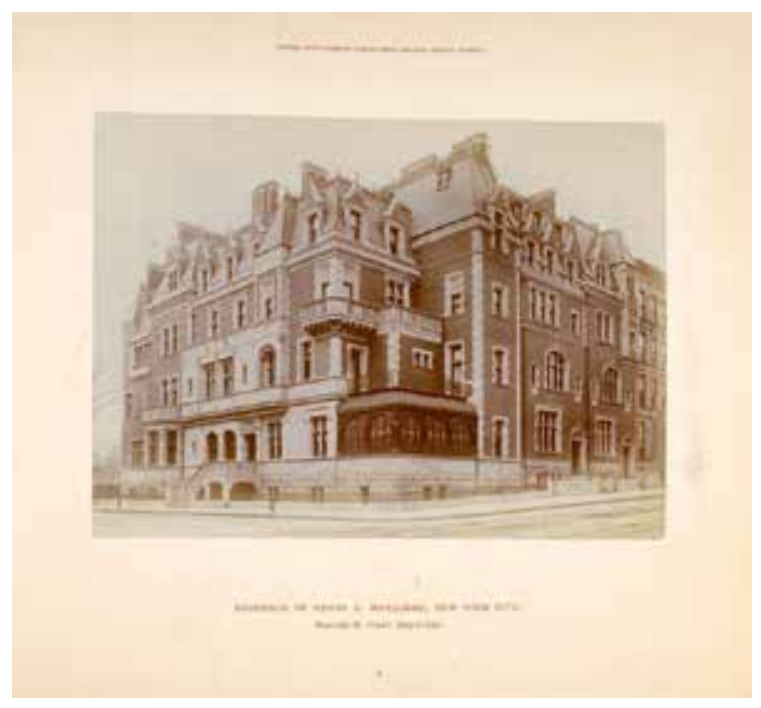

Fig. 2 Richard Morris Hunt (1827-1895), Marquand residence, Madison Avenue and Sixty-Eighth Street, New York, completed 1884; demolished 1912.

6 But Marquand was also the owner of what can be described as a second collection. ${ }^{5}$ In the early 1880s, after his retirement from active business, he had assigned himself an extraordinary mission: in order to enhance the picture holdings of the fledgling Metropolitan Museum, he had set out to assemble a group of first-class Old Masters. After all, only a few Old Masters had been added to the group of 174 works-of varying quality - that had come to the Museum in 1871, as its founding collection, known as the "Purchase of 1871." Marquand, as a contemporary later wrote, "felt sure that a group of paintings of the highest order would be unique and invaluable."

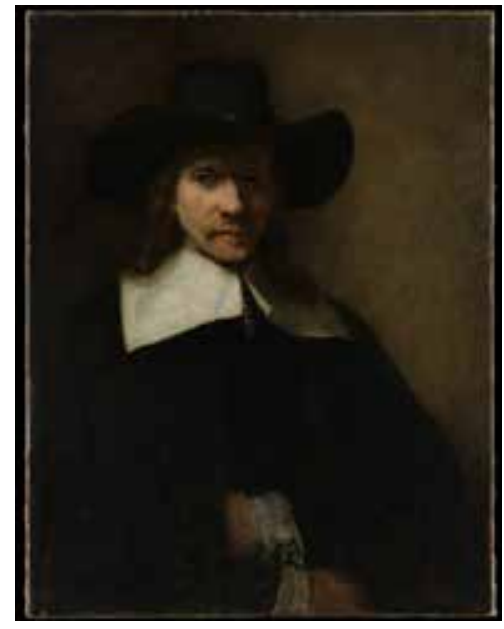

Fig. 3 Attributed to Rembrandt van Rijn (1606-1669), Portrait of a Man , ca. $1655-60$, oil on canvas, $83.5 \times 64.5 \mathrm{~cm}$. New York, The Metropolitan Museum of Art, Marquand Collection, Gift of Henry G. Marquand, 1890, inv. 91.26.7 (artwork in the public domain; photo courtesy of the Metropolitan Museum of Art)

The domestic market for Old Masters was still small and Marquand, like most of his collecting contemporaries, bought the majority of his Old Masters in Europe. He did this with the help of a large network of agents and advisers, which included expatriate painters such as George Henry Boughton, Francis Davis Millet, and J. Alden Weir, as well as London dealers such as Martin Colnaghi, Thomas Humphry Ward, and Charles Deschamps. Marquand often profited from the dire financial circumstances of the Old World's aristocrats, many of whom sold off their most esteemed artistic possessions in order to keep their estates. A strong contender in the market, he was willing to pay high prices for paintings he desired. In 1883, he purchased-for a steep \$25,000-Portrait of a Man (fig. 3), perhaps the first authentic painting by Rembrandt to come 
to America. ${ }^{7}$ Rembrandt was arguably the most coveted Old Master on both sides of the Atlantic about this time, and Marquand's acquisition may well have been inspired by the lack of a Rembrandt in the Metropolitan Museum's collection. As George Henry Boughton wrote to Marquand at the time, "by bringing such a magnificent example of such a splendid master to our country you have done every lover of art there a lasting service, for which they should be ever grateful."

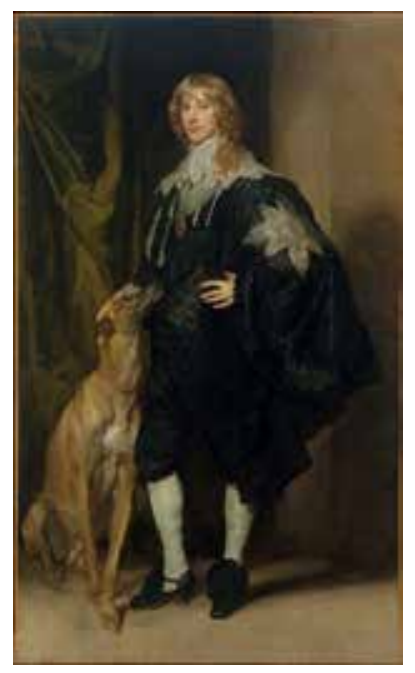

Fig. 4 Anthony van Dyck (1599-1641), James Stuart (1612-1655), Duke of Richmond and Lennox , ca. 1633-35, oil on canvas, $215.9 \mathrm{x}$ $127.6 \mathrm{~cm}$. New York, The Metropolitan Museum of Art, Marquand Collection, Gift of Henry G. Marquand, 1889, inv. 89.15.16 (artwork in the public domain; photo courtesy of the Metropolitan Museum of Art)

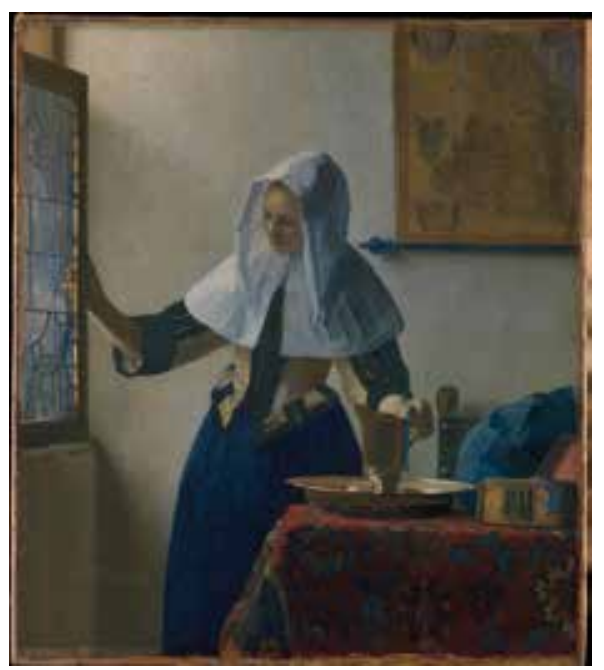

Fig. 5 Johannes Vermeer (1632-1675), Young Woman with a Water Pitcher, ca. 1662, oil on canvas, $45.7 \times 40.6 \mathrm{~cm}$. New York, The Metropolitan Museum of Art, Marquand Collection, Gift of Henry G. Marquand, 1889, inv. 89.15.21 (artwork in the public domain; photo courtesy of the Metropolitan Museum of Art)

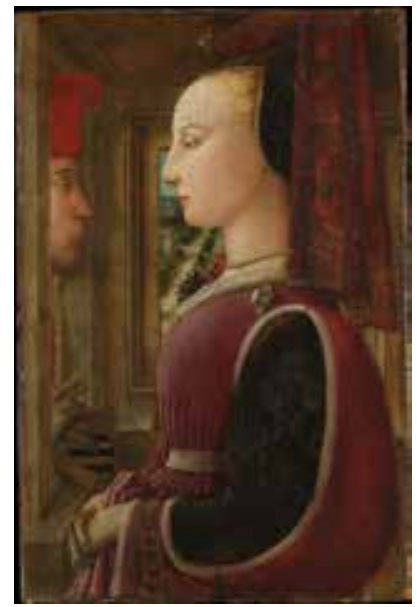

Fig. 6 Fra Filippo Lippi (ca. 1406-1469), Portrait of a Woman with a Man at a Casement , ca. 1440, tempera on wood, $64.1 \times 41.9 \mathrm{~cm}$. New York, The Metropolitan Museum of Art, Marquand Collection, Gift of Henry G. Marquand, 1889, inv. 89.15.19 (artwork in the public domain; photo courtesy of the Metropolitan Museum of Art)

Three years later, in 1886, Marquand bought the painting that many of his contemporaries considered the highlight among his Old Masters, Anthony van Dyck's James Stuart (1612-1655), Duke of Richmond and Lennox (fig. 4). Van Dyck, like Rembrandt, was one of the most admired Old Masters in the Gilded Age, and Marquand paid an exorbitant price, $\$ 40,000$, for the portrait. (Reportedly, the cost of the construction of his opulent mansion was \$125,000). Among Marquand's other notable Old Master acquisitions of the 1880s were, for example, Johannes Vermeer's Young Woman with a Water Pitcher (fig. 5), probably the first Vermeer to come to America; Filippo Lippi's Portrait of a Woman with a Man at a Casement, bought as a Masaccio (fig. 6); and Portrait of a 
Man, bought as a self-portrait by Velázquez though now considered a workshop piece, perhaps a self-portrait by Juan Bautista del Mazo. ${ }^{9}$

9 Over the years, several authors have written that Marquand's Old Masters went straight to the Metropolitan Museum upon their arrival in America and never even entered his residence. ${ }^{10}$ In fact, that was not the case, as is evident from the observations of the critic Montezuma (pseudonym of Montague Marks), who visited Marquand's mansion in 1887. ${ }^{11}$ In its entrance hall, Montezuma saw some of Marquand's most prized Old Masters: on the left wall, van Dyck's "splendid" portrait of James Stuart was flanked by Rembrandt's Portrait of a Man (see fig. 3) and a portrait presumably by Velázquez; on the opposite wall hung "two upright Constables." ${ }^{12}$ Clearly, Marquand used the entrance hall as a showcase for some of his most precious acquisitions. Montezuma also visited the mansion's music room, a gray-and-gold drawing room, also known as the Greek room, designed by Alma-Tadema in the neo-Greek-Roman style. Still unfinished, the room was already "much-talked-of," as Montezuma noted. On its walls, he saw "many modern paintings" as well as "several old masters" - including "a Franz Hals, a Van der Meer of Delft, a Terborg, a Van der Meer of Leyden, and a portrait of a young lady, full of style and delightful in color by Gainsborough." ${ }^{13}$ The residence was not open to the public.

10 In December 1888, eager to show his recent Old Master purchases to a larger audience, Marquand lent a group of thirty-seven works to the Metropolitan Museum, where they were exhibited in its new South Wing. ${ }^{14}$ The loan effected a sea change in the way New Yorkers-and, in a broader sense, Americans-were able to view art, as it introduced them directly to the works of some of the most celebrated Old Master painters, which until then only a fortunate few would have been able to see in person on their European travels. "Those who have seen the examples of Van Dyck, Rembrandt, Constable, Turner and other masters which are owned by Mr. Henry Marquand will appreciate the value of the opportunity offered by their public exhibition," wrote the New-York Tribune on December 18, 1888, the day of the South Wing's opening. "These paintings ... furnish an illustration of great art such as we have not had before. We trust that it may not be injudicious to express a hope that these superb paintings may remain at the Museum." ${ }^{15}$

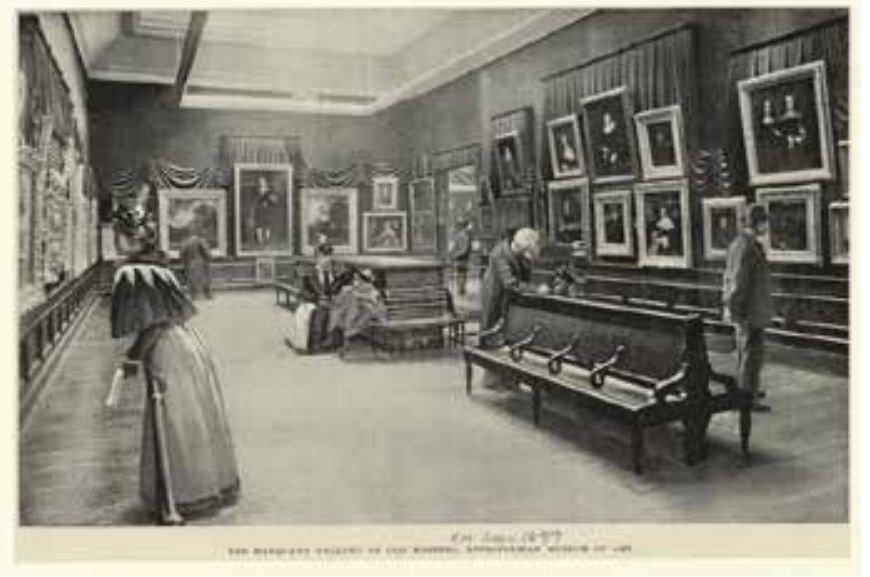

Fig. 7 The Marquand Gallery of Old Masters at The Metropolitan Museum of Art, 1897, print, $14 \times 21 \mathrm{~cm}$. Published in Harper's New Monthly Magazine, March 1897.

11 The public's enthusiastic response to the exhibition soon led to Marquand's greatest act of philanthropy: On January 10, 1889, less than a month after he had lent his paintings, Marquand donated them to the Metropolitan Museum. In a letter to its Executive Committee, he wrote that 
he had noticed the interest with "sincere pleasure," and announced that his pictures would be "of far greater service to the public to remain where they are, and in a public gallery, rather than in a private house." Requesting that they be kept together "as much as practicable," Marquand offered the works unconditionally to the museum, hoping that they would prove to be "of lasting service to the public." ${ }^{16}$ A month later, he was elected the museum's second president, a position he would keep until his death. Soon, a gallery on the museum's second floor was named the Marquand Gallery (fig. 7).

12 It was Marquand's wish that the American public, and artists in particular, benefit from his collecting efforts for years to come. At the same time, however, his charitable act was meant to serve as an example for his collecting peers, as Marquand felt compelled to use his riches to improve society and thus justify his expenditures on art. After all, as his acquaintance and fellow philanthropist Andrew Carnegie also argued in his essay "Wealth" - published in June 1889, months after Marquand made his gift-the best way of dealing with the phenomenon of wealth inequality was for the rich to give away their fortunes during their lifetimes, in such a manner that they would be redistributed responsibly and thoughtfully. ${ }^{17}$

13 Marquand's generosity did not end with his great gift of 1889; for a short time, he continued buying pictures at a swift rate, donating two smaller groups to the Metropolitan Museum in 1890 and 1891, respectively. Included in these gifts were such works as Girl with Cherries, bought by Marquand as a Leonardo da Vinci, but now attributed to the master's collaborator Giovanni Ambrogio de Predis; a small Lamentation, bought as by Jan van Eyck but now ascribed to Petrus Christus; and an excellent Frans Hals, Portrait of a Man. ${ }^{18}$ After 1891 Marquand made only a few more purchases for the museum; ironically, the market for Old Masters that he had helped to create only a decade earlier was now quickly becoming too expensive for him.

14 In 1893, Wilhelm Bode, the renowned director of Berlin's Royal Gallery and one of Europe's great tastemakers for Old Masters, came to America, where he visited several of its "new" museums - among these the Metropolitan Museum - as well as a number of private collections. Bode was "surprised" by what he saw in New York, as he confessed to the New York Times: "The public feeling for art, the architecture, the fortunes spent in public and private collections, the general interest in doing things that are magnificent, are the characteristics about which I constantly think." Gifts were much more frequent in New York than in Berlin, Bode observed, and he was much impressed by what he saw at the Metropolitan Museum. As the New York Times wrote, "the treasures gathered by Mr. Marquand made [Bode's] eyes scintillate." 19

15 After Marquand's death, in 1902, the New York Times described him as "the steadiest and most persistent benefactor of the Metropolitan Museum of Art." And indeed, it was through Marquand, and through others who followed his lead, that the Metropolitan Museum has become "really one of the museums not merely of the United States, but of the world," as the New York Times wrote more than a century ago. ${ }^{20}$

\section{Acknowledgments}

This essay is dedicated with deep gratitude and admiration to the memory of Walter Liedtke. 
Walter briefly described Marquand's 1889 gift to the Metropolitan Museum of Art in his pioneering essay on the collecting history of seventeenth-century Dutch art in the United States, "Dutch Paintings in America: The Collectors and Their Ideals," in Great Dutch Paintings from America, ed. Ben Broos (The Hague: Mauritshuis/Zwolle: Waanders, 1990), 14-59 (for Marquand, see p. 36).

Esmée Quodbach studied art history at Utrecht University, Netherlands. She is the Assistant Director of the Center for the History of Collecting at the Frick Collection and Art Reference Library, New York, and has a particular interest in the history of Old Master collecting in the United States. Prior to coming to the Frick, she held research positions at the National Gallery of Art, Washington, D.C., and the Metropolitan Museum of Art, New York. Her publications include"The Age of Rembrandt in New York: Dutch Paintings in the Metropolitan Museum of Art" (Metropolitan Museum of Art Bulletin, 2007), and she served as the editor of Holland's Golden Age in America: Collecting the Art of Rembrandt, Vermeer, and Hals (2014). Her current research focuses on the history and reception of the paintings by Johannes Vermeer that are now in the United States.

e.quodbach@gmail.com

\section{List of Illustrations}

Fig. 1 John Singer Sargent (1856-1925), Henry Gurdon Marquand (1819-1902), 1897, oil on canvas, 132.1 x $106 \mathrm{~cm}$. New York, The Metropolitan Museum of Art, Gift of the Trustees, 1897, inv. 97.43 (artwork in the public domain; photo courtesy of the Metropolitan Museum of Art)

Fig. 2 Richard Morris Hunt (1827-1895), Marquand residence, Madison Avenue and Sixty-Eighth Street, New York, completed 1884; demolished 1912.

Fig. 3 Attributed to Rembrandt van Rijn (1606-1669), Portrait of a Man, ca. 1655-60, oil on canvas, 83.5 x $64.5 \mathrm{~cm}$. New York, The Metropolitan Museum of Art, Marquand Collection, Gift of Henry G. Marquand, 1890, inv. 91.26.7 (artwork in the public domain; photo courtesy of the Metropolitan Museum of Art)

Fig. 4 Anthony van Dyck (1599-1641), James Stuart (1612-1655), Duke of Richmond and Lennox , ca. 1633-35, oil on canvas, 215.9 x $127.6 \mathrm{~cm}$. New York, The Metropolitan Museum of Art, Marquand Collection, Gift of Henry G. Marquand, 1889, inv. 89.15.16 (artwork in the public domain; photo courtesy of the Metropolitan Museum of Art)

Fig. 5 Johannes Vermeer (1632-1675), Young Woman with a Water Pitcher, ca. 1662, oil on canvas, 45.7 x $40.6 \mathrm{~cm}$. New York, The Metropolitan Museum of Art, Marquand Collection, Gift of Henry G. Marquand, 1889, inv. 89.15.21 (artwork in the public domain; photo courtesy of the Metropolitan Museum of Art)

Fig. 6 Fra Filippo Lippi (ca. 1406-1469), Portrait of a Woman with a Man at a Casement, ca. 1440, tempera on wood, 64.1 x $41.9 \mathrm{~cm}$. New York, The Metropolitan Museum of Art, Marquand Collection, Gift of Henry G. Marquand, 1889, inv. 89.15.19 (artwork in the public domain; photo courtesy of the Metropolitan Museum of Art) 
Fig. 7 The Marquand Gallery of Old Masters at The Metropolitan Museum of Art, 1897, print, $14 \mathrm{x}$ $21 \mathrm{~cm}$. Published in Harper's New Monthly Magazine, March 1897.

${ }^{1}$ For Marquand's biography, see "Henry Gurdon Marquand," Dictionary of American Biography (New York: Charles Scribner's Sons, 1936); available through Biography in Context, online, last accessed January 8, 2016. The Henry Gurdon Marquand Papers, Archives, Metropolitan Museum of Art (hereafter: HGMP, MMA), contain Marquand's correspondence with artists and dealers, as well as other materials that document his activities as a collector and patron. A detailed account of Marquand as a picture collector remains to be written. For various aspects, see Cynthia Saltzman, Old Masters, New World: America's Raid on Europe's Great Pictures 1880-World War I (New York: Viking, 2008), 20-26; Adrianna M. Del Collo, "Cultivating Taste: Henry G. Marquand's Public and Private Contributions to Advancing Art in Gilded Age New York" (M.A. thesis, Hunter College, City University of New York, 2011). The present author has written on Marquand on several occasions; see, for example, Esmée Quodbach, “The Age of Rembrandt in New York: Dutch Paintings in the Metropolitan Museum of Art," Metropolitan Museum of Art Bulletin 65, no. 1 (Summer 2007); 10-14; also see note 7 below. A longer article focusing on Marquand's collecting and philanthropy is currently in preparation and will be published in a forthcoming anthology, edited by Margaret Laster and Chelsea Bruner (working title: New York, Cultural Capital of the Gilded Age).

${ }^{2}$ Metropolitan Museum of Art (hereafter MMA), inv. 81.11.

${ }^{3}$ For the Marquand residence (demolished in 1912), see Daniëlle O. Kisluk-Grosheide, “The Marquand Mansion," Metropolitan Museum Journal 29 (1994): 151-81; Melody Barnett Deusner, “In seen and unseen places': The Henry G. Marquand House and Collections in England and America," Art History 34, no. 4 (September 2011): 754-73. For Marquand's personal collection, see The Collection of the Late Henry G. Marquand, sale cat., American Art Association, New York, January 23-31, 1903 (Lugt 60749). http://dx.doi.org/10.2307/1512966http://dx.doi.org/10.1111/j.1467-

\section{$\underline{8365.2010 .00845 . x}$}

${ }^{4}$ It is now in the Philadelphia Museum of Art (George W. Elkins Collection, 1924, inv. E1924-41).

${ }^{5}$ The distinction between the two collections formed by Marquand was made as early as 1903, in The Times of London, as noted in Del Collo, "Cultivating Taste," 6.

${ }^{6}$ E. A. Alexander, "Mr. Henry G. Marquand," Harper's New Monthly Magazine 94, no. 562 (March 1897): 566.

${ }^{7}$ MMA, inv. 91.26.7. For this acquisition, see also Esmée Quodbach, “Rembrandt's “Gilder” Is Here': How America Got Its First Rembrandt and France Lost Many of Its Old Masters," Simiolus: Netherlands Quarterly for the History of Art 31, nos. 1-2 (2004): 90-107, where it is argued that it is more likely that Herman Doomer (MMA, inv. 29.100.1), which arrived in New York in 1884, was the first authentic Rembrandt to come to America. The definitive attribution to Rembrandt of Marquand's Portrait of a Man is hampered by its poor condition; see Walter A. Liedtke, Dutch Paintings in the Metropolitan Museum of Art (New York: Metropolitan Museum of Art/New Haven: Yale University Press, 2007), 2:676-78, cat. 155. http://dx.doi.org/10.2307/4150579 ${ }^{8}$ Letter (from London), Boughton to Marquand, March 12, 1884. HGMP, MMA, box 1, folder 1, 
item 11.

${ }^{9}$ Now all MMA; see, respectively, inv. 89.15.21 (Vermeer); inv. 89.15.19 (Lippi); inv. 89.15.29 (Workshop of Velázquez). For Marquand's purchase of the Vermeer, see Esmée Quodbach, "America's First Vermeer: Young Woman with a Water Pitcher in the Metropolitan Museum of Art," Collecting for the Public. Works that Made a Difference, edited by Bart Cornelis, et al. (London: Paul Holberton Publishing, 2016) 78-83, where some of the information in this essay is presented in a different form.

${ }^{10}$ This may well have been first stated by Albert Ten Eyck Gardner in "Metropolitan People and Pictures," Art News 52, no. 9 (January 1954): 33, and thereafter repeated by others; see, for example, Kisluk-Grosheide, “The Marquand Mansion," 151; and Del Collo, "Cultivating Taste," 76. ${ }^{11}$ Montezuma [Montague Marks], "My Note Book," Art Amateur: A Monthly Journal Devoted to Art in the Household 18, no. 1 (December 1887): 2.

${ }^{12}$ The presumed Velázquez (described as "one of [his] many portraits of Don Balthazar, the little son of Philip IV”) was later entitled Portrait of Prince Baltasar Carlos and given to Velázquez's workshop, It was part of Marquand's 1889 gift to the MMA (inv. 89.15.31) but later deaccessioned. The two "upright Constables" ("The Lock" and "a characteristic village scene") may perhaps have been The Lock on the Stour and Dedham Vale. The Lock on the Stour, seen in Marquand's collection in 1888 and part of his 1889 gift, was later also decaccessioned. Last recorded on the New York art market in 1956, it, is now considered a copy, perhaps by John Dunthorne after Constable's Lock in the Philadelphia Museum of Art; see Richard Dorment, British Painting in the Philadelphia Museum of Art from the Seventeenth through the Nineteenth Century (Philadelphia Museum of Art, 1986), 55, no. 3. Dedham Vale remained in Marquand's private collection until it was sold as part of his estate in 1903; see Marquand sale, 1903, lot. no. 35 (note 3 above). Its present whereabouts are unknown.

${ }_{13}^{13}$ The Hals was most likely The Smoker (MMA, inv. 89.15.34). The "Terborg" was most likely ter Borch's Portrait of a Seated Man (MMA, inv. 89.15.15), although according to the MMA's current provenance Marquand did not buy it until 1888-89. The "Van der Meer [sic] of Leyden" may well be the first of the two works that Marquand purchased as by Lucas van Leyden, Joseph Interpreting the Dreams of Pharaoh (MMA, inv. 89.15.20), now attributed to Jörg Breu the Younger. The Gainsborough was A Boy with a Cat-Morning (then known as "A Girl with a Cat," MMA, inv. 89.15.8). A few photographs of the Marquand mansion's music room in its later, finished state, and hung with different paintings, survive; see Kisluk-Grosheide, “The Marquand Mansion,” 157, figs. 7-9. http://dx.doi.org/10.2307/1512966

${ }^{14}$ See General Guide to the Metropolitan Museum of Art Exhibition of 1888-89 (New York: Metropolitan Museum of Art, [1888]), 9-10.

15 “The Metropolitan Museum: Winter Opening," New-York Tribune, December 18, 1888.

${ }^{16}$ Letter, Marquand to the MMA Trustees, January 10, 1889, as cited in Del Collo, "Cultivating Taste," 89; also paraphrased in “The City's Art Treasures," New York Times, January 17, 1889.

${ }^{17}$ Andrew Carnegie, "Wealth," North American Review 148, no. 391 (June 1889): 653, 657-62. Carnegie's essay was later published under its more famous title, “The Gospel of Wealth," in Pall Mall Gazette, a London newspaper.

${ }^{18}$ Now all MMA, see, respectively, inv. 91.26 .5 (de Predis); inv. 91.26.12 (Christus); inv. 91.26.9 (Hals).

19 "Criticised by an Expert. Dr. Wilhelm Bode Talks about Art in this Country," New York Times, October 11, 1893. 
20 “Henry G. Marquand," New York Times, February 27, 1902.

\section{Bibliography}

Alexander, E. A. “Mr. Henry G. Marquand." Harper's New Monthly Magazine 94, no. 562 (March 1897): 560-71.

[American Art Association]. The Collection of the Late Henry G. Marquand. Sale cat. January 23-31, 1903. New York, 1903 (Lugt 60749).

Carnegie, Andrew. "Wealth." North American Review 148, no. 391 (June 1889): 653, 657-62.

Del Collo, Adrianna M. “Cultivating Taste: Henry G. Marquand's Public and Private Contributions to Advancing Art in Gilded Age New York." M.A. thesis, Hunter College, City University of New York, 2011.

Deusner, Melody Barnett. "'In seen and unseen places': The Henry G. Marquand House and Collections in England and America." Art History 3, no. 4 (September 2011): 754-73. http://dx.doi. org/10.1111/j.1467-8365.2010.00845.x

Dorment, Richard. British Painting in the Philadelphia Museum of Art from the Seventeenth through the Nineteenth Century. Philadelphia Museum of Art, 1986

Gardner, Albert Ten Eyck. “Metropolitan People and Pictures.” Art News 52, no. 9 (January 1954): $31-35,71-72$.

Kisluk-Grosheide, Daniëlle O. “The Marquand Mansion.” Metropolitan Museum Journal 29 (1994): 151-81. http://dx.doi.org/10.2307/1512966

Liedtke, Walter A. Dutch Paintings in the Metropolitan Museum of Art. 2 vols. New York: Metropolitan Museum of Art/New Haven: Yale University Press, 2007.

Metropolitan Museum of Art. General Guide to the Metropolitan Museum of Art Exhibition of 1888-89 [Marquand Collection]. New York: Metropolitan Museum of Art, [1888].

Montezuma [Montague Marks]. "My Note Book." Art Amateur: A Monthly Journal Devoted to Art in the Household 18, no. 1 (December 1887): 2.

Quodbach, Esmée. “'Rembrandt's “Gilder” Is Here’: How America Got Its First Rembrandt and France Lost Many of Its Old Masters." Simiolus: Netherlands Quarterly for the History of Art 31, nos. 1-2 (2004): 90-107. http://dx.doi.org/10.2307/4150579

Quodbach, Esmée. “The Age of Rembrandt in New York: Dutch Paintings in the Metropolitan Museum of Art.” Metropolitan Museum of Art Bulletin 65, no. 1 (Summer 2007).

Quodbach, Esmée. “America’s first Vermeer: Young Woman with a Water Pitcher in the Metropol- 
itan Museum of Art." In Collecting for the Public. Works that Made a Difference, ed. Bart Cornelis, et al., 78-83. London: Paul Holberton Publishing, 2016.

Saltzman, Cynthia. Old Masters, New World: America's Raid on Europe's Great Pictures 1880World War I. New York: Viking, 2008.

Recommended Citation:

Esmée Quodbach, "Collecting Old Masters for New York: Henry Gurdon Marquand and the Metropolitan Museum of Art," JHNA 9:1 (Winter 2017), D0I: 10.5092/jhna.2017.9.1.2 